\title{
Tempering the Cosmic Scope Problem in Christian Soteriology: Hylemorphic Animalism and Gregory of Nazianzus
}

Christianity consists of a deposit of faith which includes an articulation of certain beliefs that its adherents affirm. ${ }^{1}$ Among these beliefs stands the claim that the Incarnation and Atonement reconciled bumanity to God; that is, the deposit of faith tells us that the scope of the work of Christ includes humanity. ${ }^{2}$

But the scope of redemption does not stop at humanity, for the Christian scriptures claim that,

${ }^{19}$ [In Christ] all the fullness of God was pleased to dwell, ${ }^{20}$ and through him to reconcile to himself all things, whether on earth or in heaven, making peace by the blood of his cross. ${ }^{3}$

What we find in this passage is the claim that the scope of redemption is radically inclusive. Indeed, it is so inclusive as to exclude no type of created thing whatsoever (i.e. as indicated by the 'all things, whether on earth or in heaven $\left.{ }^{4}\right)$. In other words, this passage teaches that Christ's redemptive work has cosmic scope. ${ }^{5}$

So, belief that Christ's redemptive work extends to humanity and the rest of the cosmos belongs to the deposit of faith. This much is not especially controversial. But when it comes to the mechanics of such redemption or attempts to explain how the benefits of Christ's redemptive work might extend to the cosmos, little reflection has been carried out. It is the purpose of this essay to fill

\footnotetext{
${ }^{1} \mathrm{I}$ am not assuming any sort of view on the nature of saving faith and whether or not it has any particular cognitive commitments (e.g. that God exists, that the Kingdom of God is here, etc.). For one recent attempt to argue against the inclusion of cognitive commitments in Christianity, see (Kvanvig 2018, chapter 4). For questions of doctrines of assurance closely related to these issues, see (Rutledge 2017).

2 It's not important for the purposes of this paper to discuss debates about Unlimited vs. Limited (or singular/particular) Atonement. For questions concerning that, see (Crisp 2014).

${ }^{3}$ Colossians 1:19-20 (ESV). All biblical citations, unless noted otherwise, will be in this translation. (Bonting 2003, 599) cites 2 Corinthians 5:19 in this regard, but the referent of 'the world' (kosmon) is not the actual cosmos. The referent is all humankind, so this verse is inapt to make the point.

4 There is a type-token ambiguity here. The verse could mean either all token things on beaven and earth are reconciled to God (including every individual human or every individual atom) or all kinds of things on heaven and earth are reconciled to God (though possibly some tokens of each type are in fact not reconciled to God). I take it that context and Christian tradition both suggest the latter interpretation is the proper one; and thus, there is no quick argument to universalism from this verse alone.

${ }^{5}$ One referee helpfully suggested that the sorts of things that are reconciled together are persons, and neither of the referents of 'humanity' or 'humankind' count as persons. I have two reflections to offer in this regard. First, claiming that humanity could not count as a person is at least controversial. See (List and Pettit 2011), (Tollefsen 2015), and (Cockayne forthcoming) for reasons to think otherwise. Second, I do not wish to commit to a particular ontology of groups, so I offer the following as a reductionist-friendly translation of the claim that "humankind/humanity was reconciled to God": there was some obstacle to union with God (e.g. a metaphysically congenital condition partly constituting original sin) that attached to any individual human. Moreover, the Assumption healed that condition for any individual human who subsequently opted to participate in the New Covenant following Jesus' sacrifice.
} 
that lacuna by offering a partial explanation for how Christ's redemptive benefits might be rightly said to have cosmic scope.

To adequately address this cosmic scope problem, however, it will not suffice to consider only the general question of how Christ's work might extend to all creation in the same way. It is, of course, worth considering whether or not this could be the case, but it seems that there is one particular possibility that creates special difficulties for such an approach.

This particular possibility is the potential for the discovery of extra-terrestrial intelligences (henceforth, 'ETIs') who bear a certain similarity to humanity with respect to (i) cognitive ability and (ii) the possession of a species-specific history which includes at least one immoral action resulting in a Fall. ${ }^{6}$ The reason this particular case is more difficult is that Christ's assumption of a buman nature is motivated by the fact that humankind, in $\mathrm{Adam}^{7}$, committed a primal sin resulting in a corrupted nature the healing of which could be achieved only by its divine assumption. ${ }^{8}$ Thus, if we were to learn of the existence of ETIs as described here, we should consider whether their nature similarly admits of some form of corruption that could only be healed (i.e. only redeemed) by a divine assumption of their alien nature. If so, then the discovery of such alien life would seem to entail (given certain plausible assumptions) that the Godhead assumed (or would assume) more than one non-divine nature. That is, given such a discovery, it appears that Christians would need to posit the actuality of multiple incarnations. I ultimately argue, however that this apparent need for multiple incarnations is nothing more than apparent. ${ }^{9}$

In this paper, I offer an account of human nature (i.e. a view which has come to be known as bylemorphic animalism) which tempers the difficulties of explaining how Christ's work can have cosmic scope in the two ways briefly delineated above. I say that my account 'tempers the difficulties' because I do not claim that it solves all of those difficulties. Nonetheless, my proposed solution makes the cosmic scope problem of Christian soteriology less worrisome in important respects, and so, deserves consideration among other attempts to address similar issues. ${ }^{10}$

\footnotetext{
6 The special case of humanity's redemption is made theologically intelligible by the posit of a fall. For a trenchant discussion of significant theological developments in the history of doctrines of original sin and the Fall, see (McFarland 2010).

7 There is no commitment to a historically literalistic reading of Genesis here. Indeed, we can take the more permissive view of reading Adam as archetypal of all humankind if we so choose without inconsistency of the positions defended in this paper.

8 This claim does not depend on a denial of the Incarnation Anyway school of thought. Incarnation Anyway advocates can allow that incarnation is overdetermined because the number of sufficient reasons for God to become incarnate is greater than one. The above account could be made into an Incarnation Anyway position by simply adding the thesis that healing the effects of the primal sin is only one of the multiple sufficient reasons for incarnation.

9 (Peters 2018) offers four approaches to the question of the salvation of ETIs involving combinations of either fix-abroken-creation or incarnation-anyway models of the divine motivations for incarnation, along with either positing a single or multiple incarnation approach. The only logically incompatible theses involved here, however, are the single or multiple incarnation models. The fix-a-broken-creation and incarnation-anyway approaches are co-instantiable.

10 As one referee has helpfully suggested, someone could plausibly offer a metaphysical idealism in the tradition of Bishop Berkeley that would overcome the theological objection I advance against substance dualism's ability to overcome the
} 
Allow me, then, to briefly outline the structure of what follows. I begin in $\$ \mathbf{1}$ with an attempt by Sjoerd L. Bonting to address the general question of how Christ's work might cover all of creation in one fell swoop. ${ }^{11}$ On my reading of Bonting, his solution only works by assuming a principle of Christology due to Gregory of Nazianzus; namely, that that which is not assumed is not redeemed. Although I accept Gregory's Principle (henceforth, 'GP'), I do not accept the interpretation of it required for the validity of Bonting's argument. In place of Bonting's solution to the general question of the cosmic scope of Christ's work, then, I offer my own account according to which we distinguish between fundamental redemption, which belongs only to humankind, and derivative redemption, which belongs to anything negatively affected by the free moral decisions of human creatures.

With the general question of Christ's redemptive scope sufficiently dealt with, I turn in $\$ 2$ to the particular question concerning the possible discovery of ETIs (which are like us in the important respects detailed above). Oliver Crisp, in his paper on multiple incarnations ${ }^{12}$, presents the materials for a promising strategy for addressing this concern. In summary, he claims that human nature is, essentially, an immaterial substance which owns a corresponding body. This opens up a path for Crisp to explain how ETIs might be redeemed; namely, that such beings would also be essentially immaterial and that, in assuming a human nature, Christ would have assumed their nature as well. In other words, Crisp could solve the particular question by claiming that ETIs would be buman, and consequently, fall under the umbrella of human redemption. Although this solution is particularly elegant in many respects, I argue that the combination of Crisp's preferred model of atonement (i.e. a form of penal substitution) and his substance dualist anthropology is inconsistent with GP, that is, the same principle that created trouble for Bonting. More broadly, I argue in this section that if someone, such as Crisp, wishes to endorse a substance dualist anthropology in which they identify what is essentially human with an immaterial soul, then unless they also advocate a mechanism of atonement that could not possibly be satisfied by a wholly immaterial agent, their position conflicts with GP. Thus, I argue that if one affirms GP, then they will find no ultimate solution to the particular question of cosmic scope in Crisp's theology. Fortunately, not all is lost, for in $\$ 3$, I present an alternative anthropology, hylemorphic animalism, and explain how it might allow us to endorse both GP and preserve some of the charm of Crisp's approach (including retaining his penal substitutionary views on atonement if one so desires). Then, by combining my solution to the general question of cosmic scope (from $\$ \mathbf{1}$ ) with my solution to the particular question of cosmic scope in $\$ \mathbf{3}$, we arrive at a complete solution to the cosmic scope problem of Christian soteriology.

\section{The General Question: Cosmic Scope and the Assumption of Stardust}

When considering whether Christ's incarnation and atonement might possess cosmic scope, a good place to begin is by asking whether there is something, perhaps a property or some type of

cosmic scope problem. I agree; however, on the assumption that metaphysical idealism is not a significant option for many theologians, I present my hylemorphic animalist picture as a more traditional alternative. That being said, there has been a sophisticated resurgence of metaphysical idealism in some Christian circles in recent years: (Adams 2007), (Farris and Hamilton 2016), and (Cowan and Spiegel 2016).

11 See (Bonting 2003).

12 See (Crisp 2008). 
material part, that Christ shared with all things in virtue of becoming incarnate. ${ }^{13}$ And perhaps we might think that in sharing such a part, it might be reasonable to think that Christ's assumption of such a part would imply the extension of his redemptive work to all things as well. This strategy is pursued by biochemist and theologian Sjoerd Bonting, who writes,

Everywhere in the universe the same chemical elements are present as on Earth [...and] as far as we know, the earthly physical and chemical laws are valid throughout the universe. We can therefore make some predictions about extraterrestrial life. Such life will be based, like all earthly life, on carbon chemistry, since carbon is the only element able to form the long-chain compounds...essential for the complex processes of growth and replication of living cells. ${ }^{14}$

Later in this article and in light of the biochemistry that would inevitably be shared between Jesus' human nature and the rest of creation, Bonting suggests,

In this way, we humans have part in, are united with, the entire cosmos [because we] are made of stardust [i.e. the same fundamental types of material parts, such as carbon atoms]. Jesus, being fully human, also shares in this cosmic union, and thus through the incarnation he becomes the cosmic Christ. ${ }^{15}$

In this passage, we find an argument for why Christ's sharing material parts (henceforth, 'stardust') with all of creation has redemptive implications for the entire cosmos. Here is one way of representing that argument ${ }^{16}$ :

\section{Saving Stardust Argument}

1. In assuming a human nature, Christ assumed stardust.

2. Something is redeemed if it is assumed in the incarnation.

Therefore,

3. Stardust is redeemed (from $1 \& 2$ ).

4. Creation is made out of stardust (and nothing else).

Therefore,

5. All of creation is redeemed (from $3 \& 4$ ).

As a non-biochemist, I am happy to allow that premise (1) is true without any reservations, and (3) and (5) seem unobjectionable insofar as they merely follow from the premises preceding

\footnotetext{
${ }^{13}$ In this paper, I do not consider the arguments of Niels Henrik Gregersen's notion of deep Incarnation. That work is motivated by the idea that the Son became flesh, as opposed to buman, with respect to the explicit affirmations of the New Testament. Nevertheless, as Christology developed, especially through the Cappodocians, the importance of the Son's assuming a buman nature is central. This paper is in keeping with that strand of the Christian tradition, although Gregersen's work is admittedly worthy of engagement in another context. See (Gregersen 2010).

14 (Bonting 2003, 593).

15 (Bonting 2003, 599).

${ }^{16}$ I say 'one way of representing that argument' because the reasoning is not made sufficiently explicit in (Bonting 2003). Without the above theses as represented by premises (2) and (4), however, it is unclear how to get to the conclusion that Christ's assumption of stardust entails that his redemptive work has cosmic scope.
} 
them. ${ }^{17}$ Thus, if we are to assess the merits of this argument, our focus must turn to premises (2) and (4). Let us take them in reverse order.

Premise (4) might strike us as odd, initially, especially if we are inclined to think that humans and other organisms are more than the sum of their parts. However, premise (4) is not incompatible with the claim that organisms are more than the sum of their parts, but rather, it is incompatible with them being composed of anything other than stardust. ${ }^{18}$

What more might there be to organisms than non-stardust components? One promising solution would be to claim that the more involved in organisms (and perhaps artifacts as well) is a particular arrangement of stardust. ${ }^{19}$ On this sort of view, mental properties and the like would supervene on (i.e. be determined by) different arrangements of stardust, but no non-stardust mereological parts would be needed to account for the new properties possessed by the organisms in question. Thus, premise (4) seems in the clear, at least, insofar as it is compatible with affirming that humans exist and are greater than the sum of their parts (i.e. something which the theological tradition would surely wish to affirm).

But what of premise (2)? Premise (2) bears a striking resemblance to a well-known principle of Christology, which I noted in the introduction, known as Gregory's Principle (GP). GP derives from historical debates concerning the Apollinarian heresy, and is used explicitly by Gregory of Nazianzus in his Epistle 101, where he writes,

If anyone has put his trust in Him as a Man without a human mind, he is really bereft of mind, and quite unworthy of salvation. For that which He has not assumed He has not healed; but that which is united to His Godhead is also saved. ${ }^{20}$

The first half of the principle, italicized in the quotation from Gregory, states a necessary condition on redemption. Put in contrapositive form, it states that something is redeemed only if it is assumed. This portion of the principle, however, is not what we find in the Saving Stardust Argument. Rather, that argument requires a sufficient condition (i.e. something is redeemed if assumed), presumably articulated by the second half of Gregory's statement where he claims, "that which is united to His Godhead is also saved."

Is the second half of Gregory's statement enough to establish the sufficient condition needed for premise (2)? It seems not, for Gregory's statement is riddled with ambiguity. To see this, notice first that not everything that was assumed by Christ required the sort of redemption called for in the case of human nature. For instance, someone might ask whether the properties being born in Bethlehem

\footnotetext{
${ }^{17}$ Despite accepting premises (3) and (5) for the sake of the argument, it is perhaps worth noting the prima facie bizarreness of claiming that "stardust is redeemed".

18 See (Van Inwagen 1990).

19 And this is a good thing since he explicitly affirms the existence of the mental. Indeed, my best guess, given what he says in (Bonting 2003, 593-594) is that he would either affirm some sort of emergence theory concerning souls or property dualism of some form.

20 Found in (Gregory of Nazianzus, "To Cledonius the Priest Against Apollinarius", 6" full paragraphs) at http://www.newadvent.org/fathers/3103a.htm.
} 
or having two buman hands (along with the arrangements of stardust simples on which they supervene) needed to be redeemed in the same sense as human nature generally. ${ }^{21}$ If the sufficient condition applied to any type of thing united to the Godhead, then the properties being born in Bethlehem and having two human hands were redeemed because assumption guarantee their redemption.

Fortunately, more charitable interpretations of Gregory are available. For instance, we might restrict the domain to which Gregory refers by excluding from it anything which is not in need of the sort of redemption awaiting human nature, such as the properties suggested in the previous paragraph. In that case, a more explicit statement from Gregory would read, "that which is in need of redemption in the way buman nature requires it and is united to His Godhead is also saved." On this version of the sufficient condition, we do not run the risk of saying that certain things are redeemed (in the way human nature is) that do not need redemption. So, if we make the requisite changes to the argument, the following results (we focus on just premises 1-3 for convenience):

1. In assuming a human nature, Christ assumed stardust.

$2^{*}$. Something which is in need of redemption in the way human nature is gets redeemed in the same sense if it is assumed in the incarnation.

Therefore,

3. Stardust is redeemed (from $1 \& 2$ ).

The problem with making this change to premise $\left(2^{*}\right)$, however, is that in order to maintain the argument's validity, another premise is needed between premises (1) and (3). Call this bridging premise (2.5) that stardust is something in need of redemption in the way human nature requires redemption. Affirming this additional premise seems odd, to say the least, even if we allow for the specialized materialist interpretation of premise (4) to inform what we say about human nature. For on that specialized materialist understanding, humans are not merely stardust, but they are arrangements of stardust with some particularly impressive properties (along with the arrangements of simples on which those properties supervene). Thus, human nature, on this view, is redeemed when the Godhead assumes stardust arranged human-nature-wise. In other words, on such an account there is no reason to think that stardust simpliciter is in need of the kind of redemption motivating the Incarnation. Rather, it would be particular arrangements of stardust that are in need of redemption.

Thus, even with the requisite changes to the argument to accommodate the insights of Gregory and the materialist understanding of what humans are, we are left with a premise-i.e. (2.5) that is theologically suspect and probably false. This alone gives us no reason to reject the conclusion that all of creation is redeemed, of course, for there might be other conditions on which the redemption of all creation is brought about; that is, conditions which honor the cosmic scope of Christ's atoning work as articulated in various biblical passages. Let us then turn to some of those

${ }^{21}$ It doesn't follow from something's being a part of a thing that it shares all properties with the whole. For instance, a whole apple is apple-shaped, but no apple stem is apple-shaped. Thus, even if human nature is in need of redemption, it does not follow that hands, which are parts of individual human substances, also share the property of needing redemption. 
passages and develop a model of the scope of redemption with which we might affirm that all creation is redeemed.

Recall the passage with which this article opened, in which we saw Paul claim that,

${ }^{19}$ For in [Christ] all the fullness of God was pleased to dwell, ${ }^{20}$ and through him to reconcile to himself all things, whether on earth or in heaven, making peace by the blood of his cross. ${ }^{22}$

The thrust of this passage was that Christ would bring about redemption for all of creation. Indeed, there are other passages that speak of a distinctive need for creation to be redeemed, such as Romans 8:19-22, which reads,

${ }^{19}$ For the creation waits with eager longing for the revealing of the sons of God. ${ }^{20}$ For the creation was subjected to futility, not willingly, but because of him who subjected it, in hope ${ }^{21}$ that the creation itself will be set free from its bondage to corruption and obtain the freedom of the glory of the children of God. ${ }^{22}$ For we know that the whole creation has been groaning together in the pains of childbirth until now.

Though these passages admit of various interpretations, the idea that all creation (i.e. the cosmos or, to use the biblical phrase, everything in heaven and earth) has undergone corruption seems clear enough. ${ }^{23}$ But little is said about the mechanism by which the corruption of creation has been or will be addressed. Admittedly, Colossians 1 claims that Christ's atoning work at least plays an important role in the redemption of all things, but how that is worked out in detail regarding humanity is left open.

There is a hint in another Pauline passage, however, that might suggest a coherent model by which we can address this issue:

17 Therefore, if anyone is in Christ, he is a new creation. The old has passed away; behold, the new has come. ${ }^{18}$ All this is from God, who through Christ reconciled us to himself and gave us the ministry of reconciliation; 24

In this passage, we learn that Christ has inaugurated the new creation, and as a result of that inauguration, the church at Corinth, to whom Paul addresses this work, has received the ministry of reconciliation. ${ }^{25}$ Thus, the redemptive work of Christ is something in which his followers might take part. Indeed, in many cases, they might be the proximate causes of the reconciliation, though perhaps

${ }^{22}$ Colossians 1:19-20.

${ }^{23}$ Someone might wonder what I mean by 'corruption' here, for creation is clearly not corrupt in the same sense as fallen humanity. If this was your thought, you would be correct. To say that there is corruption present, I mean, roughly, that the corrupted thing is not the way it should be. To distinguish between the corruption of humanity and non-human creation, we can add that there is a particular type of corruption that is applicable to humanity but not non-human creation. That corruption is the state of being morally culpable for breaking some sort of moral norm or divine command. Nevertheless, the non-human part of creation remains corrupt insofar as it lacks the order that would fully promote the flourishing of its constituents. Thus, the sort of redemption non-human creation needs is something like a reordering towards flourishing.

242 Corinthians 5:17-18.

25 Though I do not mean to imply that it is only the Corinthian church for whom this is true. Obviously, it is the community of believers (or 'faith-ers' if you prefer a less cognitively committal noun) that has received this ministry. 
we might add that their contributions to redemption are only effective because they were first redeemed by Christ's Incarnation and Atonement. In other words, I believe on the basis of these passages, and other similar ones, we can distinguish between the fundamental redemption of humankind and a derivative redemption of the cosmos with the following sort of just-so story (i.e. a story that is true, for all we know ${ }^{26}$ ):

In the beginning, God made the cosmos. God also made humanity as representatives on earth of his governance of both the earth and the cosmos of which it was a part. Tragically, humanity failed to carry out its mission of reflecting God's good governance to the rest of creation, and as a result of the subsequent poor decisions of humanity, creation was subjected to continual and increasing corruption. In addition, humanity itself suffered. In particular, its very nature was corrupted by original sin, that is, a special sort of corruption that could be healed for all humanity only (i) by the right sort of sacrificial act (ii) done by someone for whom no original sin was present (iii) on the condition that the sacrifice had to be accepted by those humans desiring its redemptive benefits. Years later in the fulness of time God deigned to take on the flesh of humanity, and in doing so, the human body-soul composite which God assumed, something which in virtue of being human possessed original sin, was cleansed of its original sin by the divine nature with which it was hypostatically united. Then, as a representative of humanity not in possession of original sin, the incarnate God offered the requisite sacrificial act which cleansed any of humanity who accepted it of their original sin in a fundamental way. ${ }^{27}$ This was an inauguration of the new creation, but not all was right, for the corruption of creation brought about previously by humanity, a corruption known as fallenness, persisted to varying degrees. Thus, the newly redeemed humanity was given the mission to take up again right governance of creation, as God's representatives, to correct the damage done. Consequently, given sufficient time for healing, all of creation would be redeemed derivatively via the reconciling ministry of redeemed humanity.

I do not claim that the above just-so story is true. I only claim that it is true for all we know. Nevertheless, it does fit the biblical narrative quite well in various places and incorporates some insights of contemporary scholarship reflecting on the image of God, nature of original sin, and the Fall itself. ${ }^{28}$ Thus, I offer it in place of the mechanism suggested by Bonting as a way to understand how the entire cosmos might receive the benefits of the work of Christ. Although it goes a long way towards explaining the cosmic scope of Christ's redemptive work, it is incomplete as it stands, for the particular question of possible fallen extra-terrestrial beings remains to be addressed. It is to this question we now turn.

\footnotetext{
26 The phrase "for all we know" signals the invocation of epistemic possibility here. I should emphasize again that my including this just-so story is neither a commitment to understanding the Genesis narrative literally nor a commitment to a historical Adam and Eve.

${ }^{27}$ I do not take the 'acceptance' clause to require reflective (cognitive) assent. So long as the human involved is disposed to accept the sacrifice in the right sort of way (whatever that is), then they accrue the benefits of the redemptive work. Additional work to deal with masked of finked dispositions might be necessary, but I leave it for the reader to work out the minutia.

${ }^{28}$ See, for example, (Middleton 2005) and (Middleton 2014).
} 


\section{The Particular Question: Do ETIs Have Souls?}

\subsection{A Cartesian Anthropology for ETIs}

In the previous section we saw one way in which the benefits of Christ's redemptive work might be extended to any parts of creation that had suffered corruption at the hands of sinful humanity but were not themselves possessed of original sin. This solution leaves unaddressed the question of whether Christ's redemptive benefits would also apply to non-human parts of the creation that were in possession of a form of original sin of their own making. In his article on the question of multiple incarnations, Oliver Crisp writes concerning the potential for salvation of ETIs in possession of something like original sin,

...there seem to be several possibilities with respect to the question of the salvation of some putative extra-terrestrial corporeal life forms. The first is that God does not save such beings and the work of Christ does not apply to them. The second [i.e. Crisp's preferred answer] is that no additional incarnation is required because the scope of Christ's work includes them as things stand. So God does save these beings, but through the work of Christ. The third option is that the work of Christ might apply to them (it is cosmic in its scope) but God has not deigned to save any of these creatures. And the fourth option is that the work of Christ does not apply to them, yet God has deigned to provide some means of salvation for these creatures. ${ }^{29}$

It is in virtue of his commitment to the uniqueness of the Incarnation, as suggested by various biblical passages, that Crisp opts for the second solution. But notice that Crisp does not offer any suggestions concerning how the work of Christ might apply to ETIs. Indeed, this is surprising given that earlier in the article he discusses how being buman was of fundamental importance in explaining the motivation behind the Incarnation. ${ }^{30}$ One might think being whatever kind of thing is fallen, then, would be sufficient to motivate an incarnation of a divine person as that kind of thing.

Despite not explaining how Christ's redemption might extend to ETIs, Crisp's essay and the reflections in the previous paragraph provide fodder for such an explanation. For perhaps if we take into account the nature of humanity and the nature of ETIs that are similar to humanity in the relevant respects-e.g. cognitive abilities and possession of original sin-then perhaps we can conclude that the ETIs under question simply are human. And if so, then ETIs would fall under the coverage of human redemption. Consider the following:

1. Christ only assumed a human nature.

2. ETIs would be redeemed in the same way humankind was redeemed.

3. Humankind was redeemed by the assumption of a human nature.

Therefore,

29 (Crisp 2008, 237).

30 See, for instance, (Crisp 2008, 235): "If no human being had fallen, there would be no motivation for the incarnation, on this view." For arguments that there would be an incarnation even without a Fall, however, see (Van Driel 2008). 
4. ETIs would be redeemed by the assumption of an ETI nature (from 2-3)

If all of the above premises are true and ETIs actually exist, then it immediately follows that

5. The nature of an ETI is the same as the nature of a human.

To see this, simply assume for reductio that (5) is false and that (1)-(4) are all true and ETIs exist. If ETIs have a different nature, because of our suppositional rejection of (5), then it would follow from not-(5) and the truth of (4) that Christ assumed an ETI (i.e. non-human) nature. That is, the rejection of (5) would entail that it is not the case that Christ only assumed a human nature. But that claim is merely the negation of premise (1). And so, assuming that (5) is false entails a contradiction, i.e. something I suggest we avoid attributing to Crisp. Thus, if we wish to suggest a way in which Crisp might retain his preferred solution to the particular question about the possible existence of ETIs, we should understand him as assenting to the truth of (5).

Assenting to (5)'s truth is insufficient, however, for explaining how it could be true. To provide an adequate explanation, then, we should attend to Crisp's preferred understanding of what humans are. In setting out his account of human ontology, Crisp remarks,

...almost all orthodox classical theologians without exception held to some form of substance dualism with respect to human persons...the [Cartesian version of substance dualism is this]: a human is an essentially immaterial substance (i.e. a mind or soul) that is contingently related to a particular parcel of matter, which it 'owns' and by means of which it is able to act in the material world (i.e. a body). ${ }^{31}$

...the majority of substance dualists hold to the [central] thesis...[of] the Cartesian account...that human persons are identical with souls and only contingently related to a certain physical body, which is not part of that human person. ${ }^{32}$

As he makes clear in the remainder of his article, Crisp affirms these two claims concerning what humans are-i.e. that they are essentially immaterial substances which we might call souls. Moreover, on this account of human persons, to be human does not require that one have a human body. Indeed, one need not have any body at all to be human. All that is necessary is that one be a soul or immaterial substance that, somehow, counts as human.

In virtue of what might a particular immaterial substance count as human as opposed to, for instance, an angel? One way to distinguish them would be to claim that although strictly speaking humans can exist as immaterial substances (and hence are only essentially immaterial), nevertheless they are normatively embodied. For a thing to be normatively embodied is for it to only function properly when embodied, and this can be true, even if it is not necessarily embodied. ${ }^{33}$ Thus, Crisp could maintain the distinction in kind between angels and humans easily enough, even if both are essentially immaterial, by claiming that humans are normatively embodied (while angels are not).

31 (Crisp 2008, 228).

32 (Crisp 2008, 228fn24).

33 See (Thornton MS, 3). 
But even if Crisp can distinguish between the nature of humans and the nature of angels in this way, one might wonder whether there are other creatures that are essentially immaterial while nevertheless also being normatively embodied. Any of the other creatures on earth, for instance, might meet this description on Crisp's ontology, for all we know. So, clearly, we must say more on Crisp's behalf.

If there are other necessarily immaterial but normatively embodied creatures, then perhaps Crisp can distinguish them from each other by further appeals to the notion of a kind-essence. ${ }^{34}$ In other words, he might simply claim that in the case of human beings, to be human is to be an immaterial substance that instantiates the kind-essence human, and whatever other necessarily immaterial but normatively embodied creatures there are on earth instantiate a different kind-essence (e.g. cows have bovinity and frogs have anurity).

These reflections then, allow us to offer the following as a way for Crisp to extend the benefits of Christ's redemption to ETIs were any discovered. Were any ETIs discovered, then on the assumption that they were relatively similar to humankind, we would have good reason, given the affirmations in the above argument, to hold that they are essentially immaterial but normatively embodied substances that instantiate the kind-essence humanity. In other words, they would just be human.

Suppose someone were to object, "But surely not just any ETI would be human. Even the most traditional ETIs in science fiction have bodies of a very different sort than human bodies. So, we would be crazy to think they are human!"

In reply, we might simply point out a couple of features of the anthropology just sketched. First, being normatively embodied need not entail being normatively embodied by any particular matter (e.g. carbon). And if so, then the bodies of "little green men" could count as human bodies, despite appearing quite different than the human bodies with which we are typically acquainted. Secondly, recall that having a body at all is contingent on this account of human nature, and thus, it would be surprising that something's having one sort of body rather than another would constitute a counterexample to the claim that that thing was human. The counterexample would need to appeal to something about what it is to be human-i.e. being an immaterial substance instantiating the kindessence human-rather than something contingent. ${ }^{35}$

\subsection{A Worry for Crisp}

Despite this rather elegant means of addressing the particular question of how Christ's benefits might extend to sinful ETIs were we to learn of their existence, there remains at least one concern for Crisp's account; namely, that a combination of this response to the particular question, his preferred

\footnotetext{
${ }^{34}$ See (Loux 2006) for a discussion of kind-essences, also referred to as 'substance kinds'.

35 To put the point another way: one does not sufficiently demonstrate that some $x$ is not human by appealing to a contingent feature of $x$ that is not shared by any human (other than $x$, if $x$ is in fact human). Suppose, for instance, that I am the only human alive with naturally occurring green hair, and someone says, "Look! No human I've ever met has green hair. Therefore, you are not human!" We should not be impressed with such reasoning.
} 
penal substitution model of atonement, and the motivations which underlie Gregory's Principle commits him to a theologically troubling claim; namely, that humanity could have been redeemed by means of an immaterial incarnation.

In what follows, then, I present an argument focused narrowly on Crisp's theological resources. This narrow focus, however, does not preclude my argument from having relevance to anyone other than Crisp, and the reason for this is three-fold. First, anyone who endorses both substance dualism and penal substitution, like Crisp ${ }^{36}$, is likewise committed to the theologically troubling conclusion I highlight. Second, even if someone were to deny either or both substance dualism and penal substitution, I am not aware of anyone who has drawn attention to another case purporting to demonstrate that penal substitution and substance dualism give rise to a similar theological or philosophical conflict. Thus, if my argument is sound, it introduces a further wrinkle into affirming either substance dualism ${ }^{37}$ or penal substitution ${ }^{38}$; namely, that affirming one provides a significant reason to not affirm the other. Third, perhaps you, the reader, might be inclined to raise an eyebrow at the mention of penal substitution, for it is a fairly specific model of atonement. Many readers, in fact, might be inclined to simply reject penal substitution but hold onto their substance dualist commitments in order to avoid the argument that follows. While such a move would, of course, be possible were someone wishing to evade commitment to the conclusion of the particular argument below, it is not sufficient to avoid the more general concern, and here is why.

Penal substitution is just one model of atonement among others that identifies a mechanism of atonement which might be offered by an immaterial substance instantiating the kind-essence human. I use it in the argument below given the focus on the theology of Crisp, but the words 'penal substitution' could just as easily be read as a variable into which someone might substitute their own model of atonement. After having made such a substitution, they can then ask whether the resulting premise is true (i.e. the premise that claims of a model of atonement that its mechanism of atonement could be offered by an immaterial substance). If that premise is indeed true, then the argument I present against Crisp is one with which they need to reckon as well, for it is the possibility of an immaterial substance making atonement (alongside substance dualism) that fundamentally creates the issue. Thus, rejecting penal substitution will not get someone out of the argument. They need to reject any model of atonement that permits an immaterial incarnation to offer atonement.

So, without further ado, here is the argument against Crisp's proposed solution to the particular question of extending the benefits of Christ's redemption to ETIs (call it the Crisp Argument):

\footnotetext{
36 See, for instance, (Crisp 2016). (Moreland and Craig 2017) is another good example of a popular text explicitly defending both substance dualism and penal substitution.

${ }^{37}$ For an excellent overview of the state of the art in substance dualism, see the collection of essays in (Loose, Menuge, and Moreland 2018). The recent work for who is probably the best-known defender of contemporary Cartesian dualism (i.e. the variety endorsed by Crisp here), see (Swinburne 2013).

38 The following is a representative sample of scholars defending penal substitution: (Craig 2018), (Gathercole 2015), (Hill and James III 2004), (Hill and Jedwab 2015), Jeffery, Ovey, Sach 2007), (Strabbing 2016), and (Vidu 2014).
} 
1. If Crisp's substance dualism is true, then to be human is to be an immaterial substance that instantiates the kind-essence human.

2. If to be human is to be an immaterial substance that instantiates the kind-essence human, then God could have assumed a human nature by assuming merely a human soul.

3. Human nature is all that is in need of fundamental redemption.

4. If penal substitution is true, then atonement could have been made by an immaterial incarnation.

5. If God could have assumed a human nature by assuming merely a human soul, human nature is all that is in need of fundamental redemption, and atonement could have been made by an immaterial incarnation, then some of humanity could have been redeemed by means of an immaterial incarnation.

Therefore,

6. If Crisp's substance dualism is true and penal substitution is true, then some of humanity could have been redeemed by means of an immaterial incarnation. ${ }^{39}$

Premise (1) is simply a statement of Crisp's substance dualism. Premise (2) might appear slightly more objectionable, but in essence it is merely making the claim that assuming a human soul would be sufficient for God to assume a human nature. This claim, too, seems to simply follow from Crisp's dualism. Thus, to respond to the argument, Crisp would need to deny either premises (3), (4), or (5). Let us consider the promise of rejecting these premises.

To reject premise (3) is to claim that there is something other than human nature that is in need of the sort of redemption which motivates the incarnation (i.e. the sort of redemption glossed in the phrase 'fundamental redemption'). Whatever thing other than human nature might be in need of fundamental redemption, however, must be some contingent feature of humanity. But recall our discussion of contingent features such as having two hands or being born in Bethlehem from $\$ 2$. There we saw that there was good reason to think that the motivation for Gregory's Principle excluded such contingent features of Christ's particular instantiation of a human nature. Thus, rejecting premise (3) seems problematic because it is in conflict with GP.

What about rejecting premise (4)? To reject (4) one would need to deny that an immaterial substance instantiating the kind-essence buman could suffer and perhaps also that in virtue of that suffering they could endure punishment sufficient for making atonement for the sins of humanity. However, denying that non-embodied immaterial substances (human or not) can suffer would run into theological difficulties for any realists about fallen angels and such things. In addition, there are undoubtedly many varieties of mental suffering that one can endure, and there does not seem to be

\footnotetext{
39 Allow me to emphasize that this conclusion will not be a problem for someone who affirms Berkeleyan idealism. After all, they would accept the conclusion because it would be a conditional with a false antecedent. But it is the commitment to two types of substances, one of which is immaterial and the other material, that I take to be in tension with the consequence of (6). So, this argument is not intended to cause any sort of worry for idealists of this sort.
} 
any reason to deny that such suffering could apply in principle to non-embodied immaterial substances. But lastly, and importantly, it seems that in the case of the incarnation on a penal substitution model, it is the suffering of the particular person of Jesus, one possessed of both a human and divine nature, that ultimately results in a sufficient payment for the sins of humanity. Thus, on a model such as this that claims that Christ endured an amount of suffering that would have been punishment were it applied to us, there does not seem to be any in principle reason to deny that an immaterial incarnation could provide the necessary offering for atonement.

Does anything change when we consider premise (5)? Rejecting (5) amounts to denying that it is possible that humanity might be redeemed by means of an immaterial incarnation while simultaneously affirming both that God could have undergone a merely immaterial incarnation, offered atonement as an immaterial agent, and that nothing other than human nature was in need of fundamental redemption by assumption. ${ }^{40}$ Given that incarnation and atonement just are the necessary divine contributions to the redemption of humanity, however, it seems reasonable to think that in at least some possible world where an immaterial incarnation and atonement have been made, at least one human person accepted Christ's payment for redemption. Perhaps, of course, there are also possible worlds where all human agents reject the atonement made by an immaterial Christ, but the existence of such worlds would not preclude the existence of at least one other possible world where some individual human was redeemed. So, I see no compelling reason for denying (5).

Perhaps the above reflections of the Crisp Argument are mistaken, but if they are not, there is a final response open to Crisp; namely, he might simply accept the conclusion of the argument. That is, Crisp could just admit that as he understands soteriology, humanity could have been redeemed by means of an entirely immaterial incarnation. This is not unorthodox, as far as I am aware, for he would not thereby be committed to denying that the Second Person of the Trinity actually assumed a human body. Nor would he be denying that it was most fitting for the Second Person to assume a human body. Nor would he be affirming the possibility that redemption could be achieved without the assumption of the whole of a human nature, for the assumption of a human soul would just be the assumption of the whole of a human nature. ${ }^{41}$ Nevertheless, there is something unsettling about this claim, for the general thrust of the Fall narrative, especially as found in Paul, seems to include the idea that sinful flesh is in need of redemption. ${ }^{42}$ Indeed, this might lead one to wonder whether embodiment really is a contingent matter for human beings after all. In light of this tension, and for those who find it more appealing to adopt an alternative anthropology to Crisp than an alternative model of atonement, let us consider a different anthropology not faced with such theologically uncomfortable implications.

\footnotetext{
${ }^{40}$ Interestingly, then, it is not coherent to deny both (4) and (5) because denying them both commits one to both affirming and denying the possibility of an immaterial substance making atonement.

${ }^{41} \mathrm{I}$ add this point lest someone think Crisp would here be throwing in his lot with Gnostics or those Marcionites with whom Tertullian quarreled in his "On the Flesh of Christ".

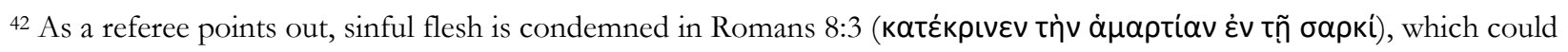
make someone skeptical of the idea that flesh is redeemed. In this paper, there is not space to defend this interpretive move, especially concerning one of the most heavily contested passages in scriptural scholarship. Nevertheless, see (Gregersen 2010) for a biblical defense of what I have assumed in the statement to which this footnote is appended.
} 


\section{Hylemorphic Animalism and the Scope of Redemption}

The worries for Crisp's account in the previous section spawned primarily from his claim concerning what human beings are. Crisp, as I understand him, claims that humans are immaterial substances possessed of the kind-essence humanity. In this section, I offer an alternative anthropology, hylemorphic animalism ${ }^{43}$, which avoids the strange theological implications accompanying Crisp's dualism while retaining his elegant response to the particular question concerning the salvation of ETIs. Let us begin with an explanation of animalism first, followed immediately by an explanation of the bylemorphic variety of it.

Animalism is the claim that we are animals, where the referent of 'we' is the set of human persons. So, animalism is the claim that buman persons are animals. If you find yourself wondering why you should believe such a thing (and it is a controversial thesis), consider the following argument which proceeds on the supposition that you are sitting in a chair.

\section{Thinking Animal Argument}

1. In your chair sits a human animal.

2. The human animal sitting in your chair is thinking.

3. But you are the only thinking being sitting in your chair.

Therefore,

4. You are the human animal. ${ }^{44}$

If someone affirms the first three premises of this argument, they must accept the conclusion. Thus, the only way out of the argument is to deny one of the first three premises.

Perhaps you deny that there are any animals; that is, perhaps you are an animal nibilist. In that case, you have a reason to deny premises (1) and (2) since they presuppose the existence of animals. Alternatively, you might deny the existence of thinking things, in which case, you have reason to deny premises (2) and (3). Still yet, you might claim that human persons are constituted by human animals without being reducible to a human animal. In that case, you might claim that while human persons think, the human animals which constitute human persons do not. If this describes you, then you have a reason to deny premise (2). Or you might even claim that both you (i.e. the human person) and the human animal are thinking, in which case you have a reason to deny (3). None of these options strike me as particularly plausible; but seeing as it is not the purpose of this paper to argue for the truth of animalism, I refrain from arguing against these (or any other) reasons for rejecting the Thinking Animal Argument. Let it suffice for me to simply stipulate that animalism is committed to accepting the soundness of the Thinking Animal Argument.

\footnotetext{
${ }^{43}$ See (Toner 2011) and (Thornton 2016) for an explanation of hylemorphic animalism. See (Olson 1997) for a discussion of a particularly interesting non-hylemorphic variety of animalism.

${ }^{44}$ See (Blatti 2016) and (Olson 2007) for variations on this argument.
} 
So, the animalist claims that human persons are animals. Yet this leaves unanswered the question, what are animals? It is in answering this question that the distinctives of bylemorphic animalism reveal themselves.

According to hylemorphists, animals are hylemorphic compounds. That is, animals are bodysoul composites that cease to exist upon losing either of those fundamental parts (i.e. either their body or the soul which animates it). ${ }^{45}$ Thus, the hylemorphic animalist is committed to denying the possibility of an animal's persisting beyond either its biological death (i.e. as an immaterial human soul) or the loss of its soul (i.e. as a dead animal). Both events are sufficient for the animal to go out of existence. ${ }^{46}$

What exactly is the soul? The soul is that part of the animal which animates it, but importantly (and unlike the understanding of soul accompanying substance dualism), the soul is not a substance. Neither is the soul an animal. For animals, on this account, must have the capacity for sensation, and immaterial souls hardly seem capable of sensation given their lack of sense organs. ${ }^{47}$ Thus, only biological organisms will count as animals on this hylemorphic view.

Yet still, what is it that differentiates one animal from another? Why is it, for instance, that frogs and cows are not humans if they too are composed of a body and soul? The answer to be given here is similar to the answer provided in our examination of Crisp's anthropology; namely, that the difference between humans, cows, and frogs is a difference in kind-essence. In other words, humans are body-soul composites that exemplify the kind-essence human, cows are body-soul composites that exemplify the kind-essence bovinity, and frogs are body-soul composites that exemplify the kindessence anurity. And each of these kind-essences can be delineated from one another on the basis of the sorts of natural capacities the instantiation of that kind-essence guarantees. Both frogs and cows must have a degree of mobility and nutritive functionality while humans must in addition have rationality. Thus, on this account intelligence is the distinguishing feature of bumanity.

These reflections might lead us to wonder whether frogs and cows are actually different kinds of creatures, metaphysically-speaking. Of course, it is undeniable that frogs and cows belong to different biological kinds. Calling this biological claim into question would be laughable. But as in many areas of philosophy, moving from biological description to metaphysical taxonomies is dubious at best $^{48}$; and thus, it is worth allowing that when it comes to the metaphysics, frogs and cows might be different biological manifestations of the same kind of being in virtue of instantiating the same kindessence (i.e. something which would happen if anurity and bovinity were identical).

\footnotetext{
${ }^{45}$ I hereby note my respectful disagreement with (Thornton MS) who claims that animals can sometimes be immaterial. Thornton's version of animalism, by such lights, would be susceptible to the same theological implications facing Crisp's form of dualism, which is part of the reason I wish to resist it.

${ }^{46}$ See (Toner 2014) for a discussion to motivate the acceptance of this line.

47 On traditional accounts, a soul by itself could compose (or be) an angel. But angels are not animals since they lack sensations, and they would instantiate the kind essence angel.

48 See (Oderberg 2007, chapter 9) for an interesting discussion of the adequacy of biological categories as determining natural kinds.
} 
Whether or not two biologically distinct species might be metaphysically of the same kind has obvious relevance to the particular question at hand, for we might ask whether ETIs and humans would instantiate the same kind-essence despite emerging from two (or more) divergent biological histories. On the hylemorphic animalist's account, I suggest that the answer to such a question would be an affirmative (i.e. they indeed might share the same kind-essence). Here's why.

When it comes to differentiating between kind-essences, we tend to appeal to differences in natural capacities the possession of which are entailed by the instantiation of a particular kind-essence. In general, then, when carving up metaphysical space, we might differentiate capacities in a coarsegrained (e.g. dividing it into nutritive, motive, and rational capacities) or fine-grained (e.g. capacities for digestion, sight, echo-location, different sorts of temporal-reasoning, self-awareness, etc.) fashion. Let us consider the implications for the particular question of the salvation of ETIs on both ways of dividing up metaphysical categories.

On the coarse-grained approach, the possession of nutritive, sensitive, and ratiocinative natural capacities would suffice for something to be human. Thus, if the coarse-grained approach were correct, then ETIs would be human in the metaphysical sense, and thus, the benefits of Christ's redemptive work would extend to them in a straightforward manner as follows. ${ }^{49}$ Christ fundamentally redeemed all humanity. All ETIs are human. Therefore, ETIs are redeemed.

Suppose, however, that we adopt the fine-grained approach. In that case, the question of metaphysics becomes much more complicated, for suppose we discover ETIs that move by, for example, echolocation. They would not be human only if the kind-essence bumanity does not give humans a natural capacity to echolocate. But, there are documented cases of human beings who routinely and successfully echolocate. ${ }^{50}$ Such cases provide evidence that humans do have a capacity to echolocate given that certain environmental parameters are in place, and thus, without knowing more about how different natural capacities relate to one another, it would be impossible to determine whether or not these aliens fell under the kind-essence human. From this it would follow that, for all we know, the ETIs in question might indeed be human.

Thus, hylemorphic animalism at least implies that no matter what ETIs we might discover in the future, it will remain epistemically possible that they possess the kind-essence human. Indeed, this would follow from either the coarse-grained or fine-grained approach to differentiating kind-essences. But on the coarse-grained approach, we could say something stronger. Were it an accurate description of the metaphysical realm, then not only would it be epistemically possible that ETIs are human but it would also follow that they are actually human.

\footnotetext{
${ }^{49}$ Interestingly, it is likely that at the metaphysical level, Christ's redemptive benefits on this account might very well extend to other Earthly animals, such as chimpanzees or dolphins, as well. If so, then the set of lifeforms in need of human-like redemption will simply be more heavily populated than we originally thought. This opens up a number of interesting questions that would take us too far from our current topic of interest (e.g. whether chimpanzees have original sin in virtue of the Adamic narrative).

50 See, for instance, this video by HD World Report describing the developments of Daniel Tish: https://www.youtube.com/watch?v=Z_E3zxx219g.
} 
Allow me, then, to conclude with some brief reflections on the implications of this result for an explanation of how the benefits of Christ's redemptive activity might apply to ETIs in the same way as it does to biological humans. If hylemorphic animalism is true, then it entails at least the epistemic possibility that the salvation of ETIs is covered by the same incarnational event that brings about human redemption. Thus, if a Christian were committed to the uniqueness of the incarnation, then they could maintain that conviction coherently and offer the above hylemorphic animalist account of what human persons are as an explanation for how the discovery of ETIs would not lead them to expect an additional incarnation to take place. Moreover, on this account, humans are not essentially immaterial substances, as on Crisp's substance dualism, and thus, Gregory's Principle does not imply any theologically untoward theoretical commitments either. Thus, it seems that hylemorphic animalism can at least temper the soteriological concerns raised by the possibility of intelligent extraterrestrial life.

\section{Conclusion}

In this paper, I have argued that the best approach to explaining how Christ's redemptive work might have cosmic scope is two-pronged. According to the first prong, we must recognize that there is a fundamental redemption applied to humankind in virtue of the Incarnation and atonement which covers human sin and a derivative redemption applied to the rest of creation in virtue of human participation in the new creation, a participation which involves resuming its proper governance of creation. According to the second prong, we must further recognize that there is a real possibility that extra-terrestrial life in need of the sort of redemption received by humanity might exist. In that case, we can explain how Christ's redemption would apply to such ETIs in virtue of their being human. I argued further, however, that substance dualist variants of this second prong committed to a penal substitution model of atonement faced a theologically troubling implication that Christ could have redeemed humanity by merely assuming an immaterial soul. In place of this substance dualist understanding of the human person, then, I offered a hylemorphic animalist account that retained the benefits of the substance dualist view without its theological costs. 


\section{Works Cited}

Adams, Robert M. 2007. "Idealism Vindicated." In Persons: Human and Divine, edited by Peter Van Inwagen and Dean Zimmerman, 35-54. Oxford: Oxford University Press.

Blatti, Stephan. “Animalism.” In The Stanford Encyclopedia of Philosophy (Winter 2016), edited by Edward P. Zalta, URL $=<$ https://plato.stanford.edu/archives/win2016/entries/animalism/>.

Bonting, Sjoerd L. "Theological Implications of Possible Extraterrestrial Life." Zygon 38, no. 3 (2003): 587-602.

Cockayne, Joshua. "Analytic Ecclesiology: the Social Ontology of the Church." Journal of Analytic Theology (forthcoming).

Cowan, Steven B. and James S. Spiegel. 2016. Idealism and Christian Philosophy: Idealism and Christianity, Volume 2. New York, NY: Bloomsbury Press.

Craig, William Lane. 2018. The Atonement. Cambridge: Cambridge University Press.

Crisp, Oliver D. 2008. "Multiple Incarnations.” In Reason, Faith and History: Philosophical Essays for Paul Helm, edited by M. W. F. Stone, 219-238. Burlington, VT: Ashgate Publishing Company.

Crisp, Oliver D. 2014. Deviant Calvinism. Minneapolis, MN: Fortress Press.

Crisp, Oliver D. 2016. The Word Enfleshed: Exploring the Person and the Work of Christ. Grand Rapids, MI: Baker Academic.

Davies, Paul. "E.T. and God: Could earthly religions survive the discovery of life elsewhere in the universe?" The Atlantic Monthly 292, no. 2 (2003): 112-118.

Farris, Joshua R. and S. Mark Hamilton. 2016. Idealism and Christian Theology: Idealism and Christianity, Volume 1. New York, NY: Bloomsbury Press.

Gathercole, Simon. 2015. Defending Substitution: An Essay on Atonement in Paul. Grand Rapids, MI: Baker Academic.

Gregersen, Niels Henrik, "Deep Incarnation: Why Evolutionary Continuity Matters in Christology." Toronto Journal of Theology 26, no. 2 (2010): 173-188.

Hill, Charles E. and Frank A James III. 2004. The Glory of the Atonement: Biblical, Historical and Practical Perspectives. Downers Grove, IL: InterVarsity Press Academic.

Hill Daniel J. and Joseph Jedwab. 2015. "Atonement and the Concept of Punishment." In Locating Atonement: Explorations in Constructive Dogmatics, edited by Oliver D. Crisp and Fred Sanders, 139-153. Grand Rapids, MI: Zondervan Academic.

Jeffery, Steve, Michael Ovey, and Andrew Sach. 2007. Pierced for Our Transgressions: Rediscovering the Glory of Penal Substitution. Wheaton, IL: InterVarsity Press.

Kvanvig, Jonathan L. 2018. Faith and Humility. Oxford: Oxford University Press. 
List, Christian and Philip Pettit. 2011. Group Agency: The Possibility, Design, and Status of Corporate Agents. Oxford: Oxford University Press.

Loose, Jonathan J., Angus J. L. Menuge, and J. P. Moreland. 2018. The Blackwell Companion to Substance Dualism. Oxford: John Wiley and Sons.

Loux, Michael. 2006. Metaphysics (3 ${ }^{\text {rd }}$ Edition). London: Routledge Publishing.

McFarland, Ian. 2010. In Adam's Fall: A Meditation on the Christian Doctrine of Original Sin. Oxford: Blackwell Publishing.

Middleton, J. Richard. 2005. The Liberating Image: The Imago Dei of Genesis 1. Grand Rapids, MI: Brazos Press.

Middleton, J. Richard. 2014. A New Heaven and a New Earth: Reclaiming Biblical Eschatology. Grand Rapids, MI: Baker Academic Publishing.

Moreland, J. P. and William Lane Craig. 2017. Philosophical Foundations for a Christian Worldview (2 ${ }^{\text {nd }}$ Edition). Wheaton, IL: InterVarsity Press.

Oderberg, David. 2007. Real Essentialism. London: Routledge Publishing.

Olson, Eric T. 1997. The Human Animal: Personal Identity Without Psychology. Oxford: Oxford University Press.

Olson, Eric T. 2007. What Are We: A Study in Personal Ontology. Oxford: Oxford University Press.

Pawl, Timothy. “Thomistic Multiple Incarnations.” Heythrop Journal 57 (2016): 359-370.

Peters, Ted. 2018. “One Incarnation or Many.” In Astrotheology: Science and Theology Meet Extra Terrestrial Life, edited by Ted Peters, 271-302. Eugene, OR: Wipf and Stock Publishers.

Rutledge, Jonathan C. “An Epistemological Corrective for Doctrines of Assurance." European Journal for Philosophy of Religion 9, no. 1 (2017): 163-177.

Strabbing, Jada Twedt. 2016. "The Permissibility of the Atonement as Penal Substitution.” In Oxford Studies in Philosophy of Religion, Volume 7, edited by Jonathan L. Kvanvig, 239-270. Oxford: Oxford University Press.

Swinburne, Richard. 2013. Mind, Brain, and Free Will. Oxford: Oxford University Press.

Thornton, Allison Krile. "Varieties of Animalism.” Philosophy Compass 11, no. 9 (2016): 515-526.

Thornton, Allison Krile. "Disembodied Animals.” (MS): http://www.allisonkrilethornton.com/wpcontent/uploads/Research/AKT-Disembodied-Animals.pdf.

Tollefsen, Deborah Perron. 2015. Groups as Agents. Malden, MA: Polity Press.

Toner, Patrick. “Hylemorphic Animalism.” Philosophical Studies 155 (2011): 65-81. 
Toner, Patrick. "Hylemorphism, Remnant Persons and Personhood." Canadian Journal of Philosophy 44, no. 1 (2014): 76-96.

Van Driel, Erwin Chr. 2008. Incarnation Anyway: Arguments for Supralapsarian Christology. Oxford: Oxford University Press.

Van Inwagen, Peter. 1990. Material Beings. Ithaca, NY: Cornell University Press.

Van Inwagen, Peter. 2004. “A Theory of Properties.” In Oxford Studies in Metaphysics (Vol. 1), edited by Dean Zimmerman, 107-138. Oxford: Oxford University Press.

Vidu, Adonis. 2014. Atonement, Law, and Justice: the Cross in Historical and Cultural Contexts. Grand Rapids, MI: Baker Academic. 